\title{
Percent Predicted Residual Volume
}

National Cancer Institute

\section{Source}

National Cancer Institute. Percent Predicted Residual Volume. NCI Thesaurus. Code C112385.

The volume of air remaining in the lungs after maximum exhalation as a proportion of the predicted normal value. (CDISC) 